\title{
Antifungal potential of essential oils from two varieties of Citrus sinensis (lima orange and bahia navel orange) in postharvest control of Rhizopus stolonifer (Ehrenb.: Fr.) Vuill.
}

\author{
Jessika Lima REZENDE ${ }^{1}$, Cassia Cristina FERNANDES ${ }^{1}$, Amanda Oliveira Mesias COSTA ${ }^{1}$, \\ Larissa Sousa SANTOS ${ }^{1}$, Francisco VICENTE NETO ${ }^{1}$, Eugenio Miranda SPERANDIO ${ }^{1}$, Edson Luiz SOUCHIE ${ }^{1}$, \\ Ana Carla COLLI², Antônio Eduardo Miller CROTTI ${ }^{2}$, Mayker Lazaro Dantas MIRANDA ${ }^{3 *}$
}

\begin{abstract}
Brazil, the world's largest citros producer, yields around 19 million tons per year and exports most part of its production as orange juice. Essential oils (EOs) extracted from leaves, fruit and flowers of many species of the genus Citrus have been widely used as the result of their promising bioactivities. The fungus Rhizopus stolonifer (Ehrenb.) Vuill., an agent which causes soft rot in fruit, has been considered one of the main factors that cause postharvest diseases, thus, leading to major economic losses in agribusiness. This research aimed at evaluating the chemical composition and in vitro antifungal effect of EOs from two varieties of fresh Citrus sinensis (lima orange and bahia navel orange) peel on mycelial growth of $R$. stolonifer. EOs were obtained by hydrodistillation, which was carried out by a Clevenger-type apparatus, while their chemical composition was analyzed by gas chromatography-flame ionization detection (GC-FID) and gas chromatography-mass spectrometry (GC-MS). Limonene was the major monoterpene identified in EOs from lima orange (95.2\%) and bahia navel orange (93.2\%) peel. EOs from lima orange and bahia navel orange inhibited $91.95 \%$ and $80.05 \%$ mycelial growth of $R$. stolonifer, respectively, at the highest dose under evaluation $(100 \mu \mathrm{L})$. This study revealed the biotechnological potential of EOs extracted from fruit peel of two varieties of citros which may applied to biofilm preparation, so as to coat and preserve different types of fruit.
\end{abstract}

Keywords: citros; alternative control; soft rot; postharvest disease.

Practical Application: Possible application of a natural product as an antifungal in the treatment of postharvest disease.

\section{Introduction}

Citriculture is the branch of fruit farming that has stood out worldwide and leads to high production of citros fruit. It was introduced in Brazil when the country was a Portuguese colony and, since then, it has been very important to consumption habits of its population. However, the country only became a global leader in orange production after 1960 and has been the world's main producer of this fruit since the mid 80's (Couto \& Canniatti-Brazaca, 2010). Despite the high production of tropical fruit, there are also many losses, which correspond to $30 \%$ of total production, on average. Postharvest losses may be the result of several causes, such as diseases caused by different types of fungi (Dantas et al., 2003).

Infestation of fungal pathogens in citros in the postharvest period usually results from inadequate field and postharvest practices, transportation and/or packaging. Control of postharvest diseases is based on balanced fertilization of groves, pruning for cleaning - and elimination of fruit with rot - and spraying of fungicides in groves from blooming to fructification (Junqueira \& Junqueira, 2014).

In the postharvest period, cold storage $\left(4-7^{\circ} \mathrm{C}\right)$ has been recommended to treat fruits and delay rot development. The literature has reported postharvest efficiency with the use of both fungicides strobilurin and prochloraz (Fischer et al., 2011). However, some countries do not allow postharvest treatment with prochloraz anymore, as the result of increasing restrictions to the use of certain fungicides in the postharvest period (Fischer et al., 2011). A sustainable alternative which aims at the use of natural products has led to recent interest in biofilms produced from EOs to coat fruit (Sousa et al., 2019). This alternative improves fruit appearance and increases preservation periods, a fact that may be explained by decrease in the transpiratory rate and metabolic activity of fungi (Fischer et al., 2011).

The fungus Rhizopus stolonifer (Ehrenb.) Vuill., an agent which causes soft rot in fruit, has been considered one of the main factors that cause postharvest diseases; it is often responsible for about $50 \%$ of loss of fruit that would be commercialized (Bassetto et al., 2007). Even though thermal and chemical treatments are the most common ones to control $R$. stolonifer and other fungi in food, the search for new antimicrobial agents based on plants has been intense due to microorganism resistance to synthetic products (Elizei et al., 2016).

The use of biodegradable films which have essential oils incorporated into them has recently become an alternative which is capable of offering benefits regarding the maintenance of food 
properties and of helping decrease the microbial load found on its surface (Prasad et al., 2018). It should be highlighted that the incorporation of substances into films not only offers the opportunity for films to interact with food, but also modifies film properties (São José et al., 2019). In addition, several studies reinforce the fact that this active packaging promotes highly efficient protection. Therefore, this study advocates that essential oils from $C$. sinensis may be used for manufacturing this type of packaging in the near future to protect certain kinds of food against contamination by $R$. stolonifer.

Considering much controversy over the use of synthetic fungicides in agriculture, due to risks posed to health and the environment, this study aimed at finding some application and/or use for fruit peel of two varieties of citros, which are considered waste in orange juice industries. Therefore, essential oils (EOs) were extracted from fruit peel of two varieties of Citrus sinensis (lima orange and bahia navel orange) and their chemical composition and in vitro antifungal activity against $R$. stolonifer were determined.

\section{Materials and methods}

\subsection{Plant material}

Fruit of both varieties of Citrus sinensis (lima orange and bahia navel orange) were purchased on February 12th, 2018, in Rio Verde, Goiás, Brazil. Fruits were washed with water, dried and peeled so that fresh peel could be collected. Both varieties of Citrus sinensis were identified by the botanist Erika Amaral and samples were deposited at the Herbarium Jataiense Professor Germano Guarim Neto at exsiccate numbers HJ \#151 (lima orange) and $\mathrm{HJ} \# 152$ (bahia navel orange).

\subsection{Extraction of EOs}

Samples of fresh C. sinensis (lima orange and bahia navel orange) peel were subjected to hydrodistillation for 2 hours by a Clevenger-type apparatus. In order to carry out the analysis, $300 \mathrm{~g}$ plant material was divided into three 100 -g samples and $500 \mathrm{~mL}$ distilled water was added to each sample. After manual collection of samples of EOs, traces of remaining water in the oils were removed with anhydrous sodium sulfate and then filtered. Isolated oils were stored under refrigeration up to the analysis and testing.

\subsection{Identification of chemical composition of EOs}

Gas chromatography (GC) analyses were performed by a Shimadzu GC2010 Plus gas chromatograph equipped with an AOC-20s autosampler and fitted with FID and a data-handling processor. An Rtx-5 (Restek Co., Bellefonte, PA, USA) fused silica capillary column (30-m x 0.25-mm i.d.; 0.25- $\mu \mathrm{m}$ film thickness) was employed. Operation conditions were as follows: the column temperature was programmed to rise from 60 to $240{ }^{\circ} \mathrm{C}$ at $3{ }^{\circ} \mathrm{C} / \mathrm{min}$ and, then, to hold at $240^{\circ} \mathrm{C}$ for $5 \mathrm{~min}$; carrier gas was $\mathrm{He}(99.999 \%)$, at $1.0 \mathrm{~mL} / \mathrm{min}$; injection mode:injection volume, $0.1 \mu \mathrm{L}$ (split ratio of 1:10); and injector and detector temperatures were 240 and $280{ }^{\circ} \mathrm{C}$, respectively. Relative concentrations of components were obtained by peak area normalization (\%). Relative areas were the average of triplicate GC-FID analyses.

GC-MS analyses were carried out by a Shimadzu QP2010 Plus (Shimadzu Corporation, Kyoto, Japan) system equipped with an AOC-20i autosampler. The column was an RTX-5MS (Restek Co., Bellefonte, PA, USA) fused silica capillary column $(30 \mathrm{~m} \times 0.25 \mathrm{~mm}$ i.d. $\times 0.25 \mu \mathrm{m}$ film thickness). Electron ionization mode occurred at $70 \mathrm{eV}$. Helium (99.999\%) was employed as the carrier gas at constant flow of $1.0 \mathrm{~mL} / \mathrm{min}$. Injection volume was $0.1 \mu \mathrm{L}$ (split ratio of 1:10). Injector and ion-source temperatures were set at 240 and $280^{\circ} \mathrm{C}$, respectively. The oven temperature program was the same as the one used for GC. Mass spectra were taken at scan intervals of $0.5 \mathrm{~s}$, in the mass range from 40 to $600 \mathrm{Da}$.

Identification of volatile components of fresh C. sinensis (lima orange and bahia navel orange) peel (Table 1 and Table 2) was based on their retention indices on an Rtx-5MS capillary column under the same operating conditions as the ones in the case of GC relative to a homologous series of $n$-alkanes $\left(\mathrm{C}_{8}-\mathrm{C}_{20}\right)$. Structures were computer-matched with Wiley 7, NIST 08 and FFNSC 1.2 spectra libraries and their fragmentation patterns were compared with literature data (Adams, 2007).

\subsection{In vitro antifungal activity of EOs from fresh C. sinensis (lima orange and bahia navel orange) peel against phytopathogen R. stolonifer}

Pathogenic isolates of $R$. stolonifer were collected in November 2018, by direct isolaton of fungal structures of infected grapes. Assays were carried out in the agricultural microbiology laboratory at IF Goiano - Campus Rio Verde and the antifungal activity of EOs from C. sinensis fruit peel were evaluated in agreement with the disc-diffusion method described by Xavier et al. (2016), at 25-100 $\mu \mathrm{L}$ doses of EOs (Figure 1 - lima orange and Figure 2 - bahia navel orange). Negative controls were dishes with no addition of EOs (witness) whereas the positive control was the fungicide Carboxin + Thiram, at $25 \mu \mathrm{g} / \mathrm{mL}$ of active ingredient. Petri dishes were sterilized and prepared with PDA culture medium. After

Table 1. Chemical composition of EOs from fresh lima orange peel.

\begin{tabular}{lcccr}
\hline \multicolumn{1}{c}{ Compound } & $\mathrm{RT}(\mathrm{min})$ & $\mathrm{RI}_{\exp }$ & $\mathrm{RI}_{\text {lit }}$ & $\mathrm{RA \%}$ \\
\hline a-Pinene & 10.08 & 936 & 939 & 0.1 \\
Myrcene & 13.56 & 991 & 992 & 0.9 \\
Limonene & 15.96 & 1030 & 1031 & 95.2 \\
Linalool & 19.93 & 1097 & 1098 & 1.0 \\
Citronellal & 23.81 & 1151 & 1153 & 1.3 \\
a-Terpineol & 24.18 & 1187 & 1189 & 0.1 \\
$\beta$-Citronellol & 28.95 & 1227 & 1228 & 1.0 \\
trans-a-Bergamotene & 37.12 & 1434 & 1435 & 0.1 \\
Germacrene D & 38.78 & 1479 & 1480 & 0.1 \\
$\beta$-Bisabolene & 39.89 & 1508 & 1509 & 0.2 \\
Total & & & & 100 \\
\hline
\end{tabular}

$\mathbf{R T}=$ Retention time; $\mathbf{R I}_{\exp }=$ Retention index determined in relation to $n$-alkanes $\left(\mathrm{C}_{8}-\mathrm{C}_{20}\right)$ on the Rtx-5MS column; $\boldsymbol{R I}_{\text {lit }}=$ Retention index from the literature (Adams, 2007); RA\% = relative area (peak area in relation to the total peak area in the GC-FID chromatogram). 
medium solidification, EOs, at the previously mentioned doses, were added and smeared on the surface of the dish with the help of a Drigalski spatula. Afterwards, $5 \mathrm{~mm}$ diameter PDA medium

Table 2. Chemical composition of EOs from fresh bahia navel orange peel.

\begin{tabular}{lcccc}
\hline \multicolumn{1}{c}{ Compound } & $\mathrm{RT}(\mathrm{min})$ & $\mathrm{RI}_{\text {exp }}$ & $\mathrm{RI}_{\text {lit }}$ & $\mathrm{RA} \%$ \\
\hline a-Pinene & 10.10 & 937 & 939 & 0.3 \\
Sabinene & 12.52 & 975 & 976 & 1.0 \\
Myrcene & 13.36 & 990 & 992 & 1.4 \\
S-3-Carene & 14.78 & 1011 & 1012 & 0.7 \\
Limonene & 15.94 & 1030 & 1031 & $\mathbf{9 3 . 2}$ \\
Linalool & 19.93 & 1097 & 1098 & 0.8 \\
Terpinen-4-ol & 25.45 & 1176 & 1177 & 0.1 \\
a-Terpineol & 26.14 & 1189 & 1189 & 0.2 \\
Decanal & 27.16 & 1203 & 1204 & 0.6 \\
Citronellol & 28.94 & 1227 & 1228 & 0.1 \\
Lauraldehyde & 35.88 & 1405 & 1407 & 0.1 \\
trans-Caryophyllene & 35.45 & 1418 & 1418 & 1.1 \\
Valencene & 38.34 & 1490 & 1491 & 0.4 \\
Total & & & & 100 \\
\hline
\end{tabular}

$\mathbf{R T}=$ Retention time; $\mathbf{R I}_{\text {exp }}=$ Retention index determined in relation to $n$-alkanes $\left(\mathrm{C}_{8}-\mathrm{C}_{20}\right)$ on the Rtx-5MS column; $\mathbf{R I}_{\mathrm{lit}}=$ Retention index from the literature (Adams, 2007); RA\% = relative area (peak area in relation to the total peak area in the GC-FID chromatogram).

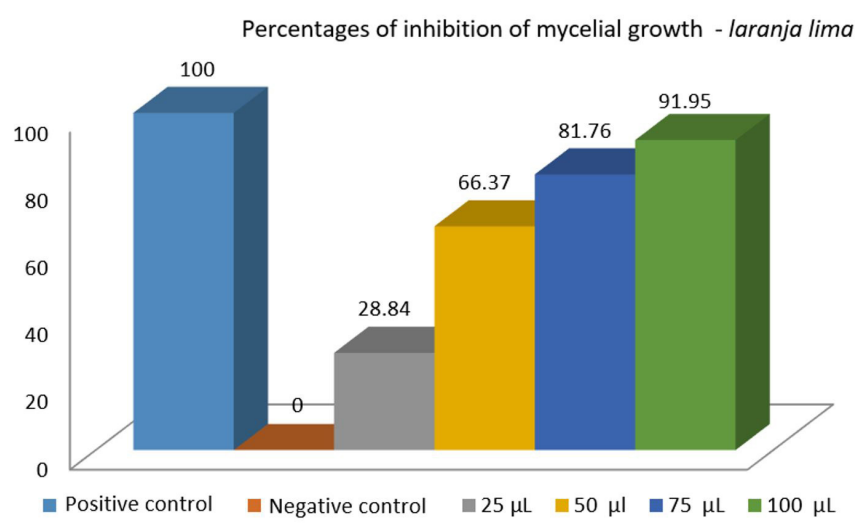

Figure 1. Percentages of inhibition of mycelial growth of $R$. stolonifer at different doses $(25-100 \mu \mathrm{L})$ of EOs from fresh lima orange peel (laranja lima in Brazilian Portuguese).

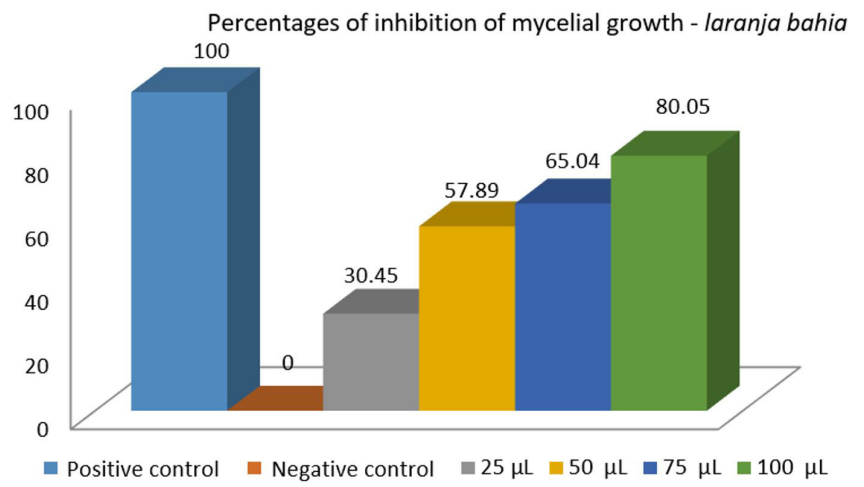

Figure 2. Percentages of inhibition of mycelial growth of $R$. stolonifer at different doses $(25-100 \mu \mathrm{L})$ of EOs from fresh bahia navel orange peel (laranja bahia in Brazilian Portuguese). discs with 10-day-old mycelia were placed in the center of the dishes. Then, they were incubated at $28 \pm 2{ }^{\circ} \mathrm{C}$. Mycelial growth was measured daily, until the fungus had fully grown on the control dishes. The treatment was carried out in quadruplicate and the experimental design was thoroughly randomized. Data were submitted to the analysis of variance (ANOVA) and the means of the treatments were evaluated by the Scott-Knott test at $5 \%$ significance level by the ASSISTAT software.

Percentage of inhibition of mycelial growth (IMG) was calculated by the following Formula 1:

$$
\operatorname{IMG}(\%)=\frac{(\text { control growth }- \text { treatment growth })}{\text { control growth }} \times 100
$$

\section{Results and discussion}

GC-MS and GC-FID identified 13 chemical constituents in EOs from bahia navel orange peel, corresponding to $100 \%$, while ten were identified in EOs from lima orange peel, corresponding to $100 \%$. Retention times, identified compounds, retention indexes and relative percentages (\%) are shown in Table 1 (bahia navel orange) and Table 2 (lima orange). The major component found in EOs from fresh fruit peel was limonene (95.2\% in lima orange; $93.2 \%$ in bahia navel orange).

In general, EOs draw attention because they are composed of mixtures of complex and volatile substances, which bestow specific aroma on plants. Besides, they act as a defense system in the vegetable kingdom, since they are sources of chemical agents that have antibacterial, insecticidal and antifungal activity; this is the case of EOs extracted from orange peel (Ferronatto \& Rossi, 2018). Regarding the enormous amount of orange peel generated by food industries, their concern is that this waste may become a problem when it is badly managed and may pose risks to the environment and the population's health. Law no. 12.305, which was issued in August 2010 by the Brazilian Policy on Residues and Solids, says that a residue is only considered refuse when all alternatives of use have been used up (Ferronatto \& Rossi, 2018).

Ferronatto \& Rossi (2018) also stated that EOs from Citrus sinensis had high contents of limonene (91.4\%), a fact that corroborates the ones found by the study reported in this paper. They added that both compounds myrcene and linalool were considered major constituents, by comparison with the other ones, even though they were found at lower amounts.

Velázquez-Nuñez et al. (2013) investigated components of EOs from orange peel and found limonene (96.6\%) as the major one, followed by other terpenes, such as myrcene $(1.72 \%)$ and $\beta$-pinene (0.53\%). Espina et al. (2011) carried out a study of Spanish orange peel and identified 56 components; the major ones were limonene (85.5\%), cis-limonene oxide $(1.03 \%)$ and myrcene $(0.92 \%)$. It should be highlighted that some studies have already shown the influence of genotypes on chemical compositions of EOs from citros; in all findings, limonene was a major constituent (Hosni et al., 2010).

Antifungal potential of EOs against postharvest phytopathogens has increasingly drawn researchers' attention worldwide (Znini et al., 2013), since these oils may act as biofungicides 
and replace chemical fungicides. Therefore, in vitro antifungal activity of EOs from fresh C. sinensis peel was evaluated against the phytopathogenic fungus $R$. stolonifer. EOs inhibited mycelial growth of R. stolonifer in a dose-dependent manner. Percentages of inhibition of mycelial growth (IMG) by EOs from fresh lima orange and bahia navel orange peel are shown in Figures 1 and 2 .

Figures 1 and 2 show data on in vitro antifungal potential of EOs from both varieties of citros peel. The fungistatic and/or antifungal effect of EOs under study may be related to their major chemical components. Lorenzetti et al. (2011) stated that EOs may contain chemical components at different concentrations, i. e., usually a major component and others, at lower concentrations, working together, may exhibit antifungal activity through a synergic effect.

According to Viuda-Martos et al. (2008), EOs from C. sinensis were found to inhibit in vitro growth of four fungal species that deteriorate food. Their highest inhibitory activity was registered against Aspergillus niger, which was kept up to the seventh day of evaluation. Reddy et al. (1998) submitted strawberries to the activity of volatile compounds of Thymus vulgaris and got satisfactory inhibitory activity against $R$. stolonifer. Vu et al. (2011) also showed that EOs may act against phytopathogens effectively when they studied the activity of EOs from Cymbopogon citratus against $R$. stolonifer. An important issue was described by Fisher \& Phillips (2008), who state that EOs from species of Citrus are "Generally Recognized as Safe" (GRAS) by the Food and Drug Administration (FDA) as food additives, a fact that enables them to be used in several food matrices.

The promising in vitro anti-Rhizopus stolonifer activity of EOs from fresh C. sinensis peel may be justified by their major chemical constituent, i. e., limonene. It may also be implied that the high antifungal activity exhibited by EOs from lima orange results from the high concentration of limonene, which was $95.2 \%$ (Table 1). This monoterpene has already shown promising activity against several types of fungi, such as different species of Candida (Viriato, 2014). On the other hand, Chee et al. (2009) described limonene as a potent antifungal against Trichophyton rubrum. In general, Jing et al. (2014) intelligently concluded that EOs from Citrus have been widely used in food and pharmaceutical industries because of their antifungal activity.

Mechanisms of action used by EOs to inhibit either microbial proliferation or even cell lysis have not been fully understood yet, since there are few studies of these mechanisms in fungi. However, Nazzaro et al. (2017) stated that the activity of EOs may take place through changes in the integrity, composition and permeabilty of cell membranes, oxidative stress, inhibition of intracell processes of ion transport and rupture of cell membranes.

\section{Conclusions}

In sum, oranges are actually part of Brazilian consumers' diet as important sources of vitamins and fibers. EOs from citros have been mainly acknowledged as compounds that carry secondary metabolites whose biological functions act either synergically together or alone. EOs from both varieties of Citrus exhibited high contents of limonene, a monoterpene that may be related to the promising in vitro antifungal activity against Rhizopus stolonifer. It should be highlighted that the antifungal activity of pure limonene against $R$. stolonifer must be evaluated in the future.

\section{Acknowledgements}

The authors are grateful to FAPEG, CNPq, CAPES and IF GOIANO for their financial support. We would like to thank Alaerson Maia Geraldine, teacher at the Phytopathology Department - IF Goiano campus Rio Verde, not only for providing fungal strains but also for enabling the use of their research laboratory.

\section{References}

Adams, R. P. (2007). In identification of essential oil components by gas chromatography/quadrupole mass spectroscopy (4th ed.). Carol Stream: Allured Publishing Corporation.

Bassetto, E., Amorim, L., Benato, E. A., Gonçalves, F. P., \& Lourenço, S. A. (2007). Efeito da irradiação UV-C no controle da podridão parda (Monilinia fructicola) e da podridão mole (Rhizopus stolonifer) em pós-colheita de pêssegos. Fitopatologia Brasileira, 32(5), 393-399. http://dx.doi.org/10.1590/S0100-41582007000500004.

Chee, H. Y., Kim, H., \& Lee, M. H. (2009). In vitro antifungal activity of limonene against Trichophyton rubrum. Mycobiology, 37(3), 243-246. http://dx.doi.org/10.4489/MYCO.2009.37.3.243. PMid:23983542.

Couto, M. A. L., \& Canniatti-Brazaca, S. G. (2010). Quantificação de vitamin $\mathrm{C}$ e capacidade antioxidante de variedades cítricas. Food Science and Technology, 30(Suppl. 1), 15-19. http://dx.doi.org/10.1590/ S0101-20612010000500003.

Dantas, S. A. F., Oliveira, S. M. A., Michereff, S. J., Nascimento, L. C., Gurgel, L. M. S., \& Pessoa, W. R. L. S. (2003). Doenças fúngicas pós-colheita em mamões e laranjas comercializados na central de abastecimento do Recife. Fitopatologia Brasileira, 28(5), 528-533. http://dx.doi.org/10.1590/S0100-41582003000500010.

Elizei, V. G., Chalfoun, S. M., Botelho, D. M. S., \& Rebelles, P. P. R. (2016) Atividade antifúngica, in vitro, do óleo de café verde. Arquivos do Instituto Biológico, 83, e1162013. http://dx.doi.org/10.1590/18081657001162013.

Espina, L., Somolinos, M., Lorán, S., Conchello, P., García, D., \& Pagán, R. (2011). Chemical composition of commercial citrus fruit essential oils and evaluation of their antimicrobial activity acting alone or in combined processes. Food Control, 22(6), 896-902. http://dx.doi. org/10.1016/j.foodcont.2010.11.021.

Ferronatto, A. N., \& Rossi, R. C. (2018). Extração e aplicação do óleo essencial da casca da laranja como um ingredient natural. Estudos Tecnológicos em Engenharia, 12(2), 78-93. http://dx.doi.org/10.4013/ ete.2018.122.05.

Fischer, I. H., Tozze, H. J. Jr., Arruda, M. C., \& Massola, N. S. Jr. (2011). Pós-colheita de abacates 'Fuerte' e 'Hass': características físicas e químicas, danos e controle de doenças. Semina: Ciências Agrárias, 32(1), 209-220. http://dx.doi.org/10.5433/1679-0359.2011v32n1p209.

Fisher, K., \& Phillips, C. (2008). Potential antimicrobial uses of essential oils in food: is citrus the answer? Trends in Food Science \& Technology, 19(3), 156-164. http://dx.doi.org/10.1016/j.tifs.2007.11.006.

Hosni, K., Zahed, N., Chrif, R., Abid, I., Medfei, W., Kallel, M., Brahim, N. B., \& Sebei, H. (2010). Composition of peel essential oils from four selected Tunisian Citrus species: evidence for the genotypic influence. Food Chemistry, 123(4), 1098-1104. http://dx.doi. org/10.1016/j.foodchem.2010.05.068. 
Jing, L., Lei, Z., Li, L., Xie, R., Xi, W., Guan, Y., Sumner, L. W., \& Zhou, Z. (2014). Antifungal activity of citrus essential oils. Journal of Agricultural and Food Chemistry, 62(14), 3011-3033. http://dx.doi. org/10.1021/jf5006148. PMid:24628448.

Junqueira, N. T. V., \& Junqueira, K. P. (2014). Principais doenças de anonáceas no Brasil: descrição e controle. Revista Brasileira de Fruticultura, 36(spe1), 55-64. http://dx.doi.org/10.1590/S010029452014000500006.

Lorenzetti, E. R., Monteiro, F. P., Souza, P. E., Souza, R. J., Scalice, H. K., Diogo, J. R. R. Jr, \& Pires, M. S. O. (2011). Bioatividade de óleos essenciais no controle de Botrytis cinerea isolado de morangueiro. Revista Brasileira de Plantas Medicinais, 13(spe), 619-627. http:// dx.doi.org/10.1590/S1516-05722011000500019.

Nazzaro, F., Fratianni, F., Coppola, R., \& De Feo, V. (2017). Essential oils and antifungal activity. Pharmaceuticals, 10(4), 86. http://dx.doi. org/10.3390/ph10040086. PMid:29099084.

Prasad, W., Khamrui, K., Mandal, S., \& Badola, R. (2018). Effect of combination of essential oils on physicochemical and sensorial attributes of burfi in comparison with individual essential oil and BHA. International Journal of Dairy Technology, 71(3), 810-819. http://dx.doi.org/10.1111/1471-0307.12512.

Reddy, M. V. B., Angers, P., Gosselin, A., \& Arul, J. (1998). Characterization and use of essential oil from Thymus vulgaris against Botrytis cinerea and Rhizopus stolonifer in strawberry fruits. Phytochemistry, 47(8), 1515-1520. http://dx.doi.org/10.1016/S0031-9422(97)00795-4.

São José, J. F. B., Medeiros, H. S., Oliveira, F. C. E., Fialho, E., Moraes, A. R., Oliveira, D. S., Medeiros, E. A. A., \& Soares, N. F. F. (2019). Development and characterization of active film with omega-3 as a proposal for enrichment of butter. Food Science and Technology, 39(Suppl. 1), 304-308. http://dx.doi.org/10.1590/fst.00618.

Sousa, H. A. F., Oliveira, J. G. Fo., Egea, M. B., Silva, E. R., Macagnan, D., Pires, M., \& Peixoto, J. (2019). Active film incorporated with clove essential oil on storage of banana varieties. Nutrition \& Food Science, 49(5), 911-924. http://dx.doi.org/10.1108/NFS-09-2018-0262.

Velázquez-Nuñez, M. J., Avila-Sosa, R., Palou, E., \& López-Malo, A. (2013). Antifungal activity of orange (Citrus sinensis var. Valencia) peel essential oil applied by direct addition or vapor contact. Food Control, 31(1), 1-4. http://dx.doi.org/10.1016/j.foodcont.2012.09.029.

Viriato, A. (2014). Terpenoides com atividade antifúngica para Candida Berkhout, causadoras de infecções hospitalares. O Mundo da Saude, 38(1), 40-50. http://dx.doi.org/10.15343/0104-7809.20143801040050.

Viuda-Martos, M., Ruiz-Navajas, Y., Fernández-López, J., \& PérezÁlvarez, J. (2008). Antifungal activity of lemon (Citrus lemon L.), mandarin (Citrus reticulate L.), grapefruit (Citrus paradise L.) and orange (Citrus sinensis L.) essential oils. Food Control, 19(12), 11301138. http://dx.doi.org/10.1016/j.foodcont.2007.12.003.

Vu, K. D., Hollingsworth, R. G., Leroux, E., Salmieri, S., \& Lacroix, M. (2011). Development of edible bioactive coating based on modified chitosan for increasing the shelf life of strawberries. Food Research International, 44(1), 198-203. http://dx.doi.org/10.1016/j. foodres.2010.10.037.

Xavier, M. N., Alves, J. M., Carneiro, N. S., Souchie, E. L., Silva, E. A. J., Martins, C. H. G., Ambrosio, M. A. L. V., Egea, M. B., Alves, C. C. F., \& Miranda, M. L. D. (2016). Composição química do óleo essencial de Cardiopetalum calophyllum Schltdl. (Annonaceae) e suas atividades antioxidante, antibacteriana e antifúngica. Revista Virtual de Química, 8(5), 1433-1448. http://dx.doi.org/10.21577/19846835.20160101.

Znini, M., Cristofari, G., Majidi, L., Paolini, J., Desjobert, J. M., \& Costa, J. (2013). Essential oil composition and antifungal activity of Pulicaria mauritanica Coss., against postharvest phytopathogenic fungi in apples. Lebensmittel-Wissenschaft + Technologie, 54(2), 564-569. http://dx.doi.org/10.1016/j.lwt.2013.05.030. 